\title{
Investigate the effect of bicycle education provided for children with autism on recognising bicycle and cycling skill
}

\author{
Bircan Kavlak ${ }^{a *}$, Zekiye Başaran ${ }^{b}$, Serap Çolak ${ }^{c}$, Mecit Kılınç ${ }^{e}$ and Osman Arslan ${ }^{d}$ \\ abcd Kocaeli University Sport Sciences Faculty 41380 Umuttepe Kocaeli / Türkiye \\ ${ }^{e}$ Mavi Otizm Sports Club Association President Tekirdağ / Türkiye
}

\begin{abstract}
The purpose of this study is to investigate the effect of bicycle training on children with autism on their ability to recognize and ride cycling. The sample of the study consisted of 33 children aged 5-17 years. The prepared program was applied for 3 days per week and 2 sessions for each child separately. "Cycling riding skill observation form for autistic individuals" which prepared by Kavlak was used as a data collection tool. The data obtained from the form was analyzed with the SPSS 22 packet program. Descriptive statistics and from dependent variables Wilcoxon Test was applied to non-normal distribution data $(p<0.05)$. At the end of study; a statistically significant difference $(\mathrm{p}=.000)$ was found between the pre-test / post-test scores of the cycling skill observation form. This difference was also found in all the items on the form. Bicycle Skill Training has been a positive influence on children with autism. And all the children who participated in the exercise learned to use bicycles. Such special trainings will help their development and maintain a happier life.
\end{abstract}

Keywords: Autism, Child, Cycling.

\section{Introduction and purpose}

Autism term was defined as "to absent itself from participating in social world" by Bleuler. Autism is a lifetime discrepancy which generally shows indications in first three years of life. [1] It is a complicated neurological disorder with multiple causes which indicates stereotype behaviors and language, communication and social interaction skills incapability [2,3,4,5,6].

Many individuals with autism have different features and they aren't always at the same similarity level. Autism intensities may be classified according to perception capabilities of individuals. Therefore, autism is not defined as illness but as a disorder [7].

Cause of autism is not known yet; however it is dwelled on that functional disorders, imbalances of releasing chemical substances in body, genetic susceptibility, environmental factors and socio-psychological reasons may be the causes $[8,9]$.

* Corresponding author: bircankav@gmail.com 
Doing physical activities regularly provides physiological, psychological and sociological benefits to people. These benefits are quite important for individuals with autism. Sports activities help children with autism to strengthen their muscles, hand-eye coordination, balance development and especially to establish social relationships which is their biggest problem. It helps to reduce adjustment disturbing behaviors. Therefore it eases to have a place in communal living for them [10].

Bicycle which became a part of daily life is a way to entertain as much as being a means of transport. Riding requires ability but everybody can learn how to ride. However a special education method is required for disadvantageous groups such as individuals with autism. Therefore to examine the effect of bicycle education provided for children with autism on recognizing bicycle and cycling skill in this study is the purpose of our research.

\section{Material method}

\subsection{Research group}

18 males and 2 females from France Agir Vivre L'autisme with 11,2 ( \pm 2.7$)$ age average and 13 male with autism from İzmit Autism Sports Club Association with $12.2( \pm 2.8)$ age average participated in research voluntarily by permission of their parents.

\subsection{Research method}

Researches were made on different dates for each individual for three days and 2 sessions (40 \pm 7 min.) in a week. Individualized educations designed by special education specialists based on students' perception capacities were applied one-to-one. Applied behavior analysis method focused on how to learn and how to change behaviors based on learning principles is used at researches [11]. To be a model, method to absent clue with physical help and verbal helps were applied. Researchers were attentive to apply education cascades in same order in both countries. Educational games were added into sessions and it was taken care of children to learn entertainingly.

\subsection{Data collection tool}

"Cycling skill of individuals with autism observation test" developed by Kaylak; one of researchers was used. Movements of children during the tests were videotaped. Then 3 trainers graded videotapes by first shoots and latest shoots according to prepared form and averaged. This from consisting on ten questions is triple likert-type and four questions evaluate level of recognizing bicycle and six questions evaluate cycling skill.

\subsection{Data analysis}

Data obtained from surveys were analyzed in SPSS 22 packaged software. Definitive statistics, frequency $(\mathrm{F})$ and percent $(\%)$ data belonging to personal information were obtained. Also nonparametric Wilcoxon Test was applied in order to test dependent variables $(\mathrm{p}<0.05)$. Cronbach's Alpha was determined as 918 .

Table.1 Definitive Statistics belonging to Participants

\begin{tabular}{|c|c|c|c|c|c|}
\hline & N & Minimum & Maximum & Mean & Std. Deviation \\
\hline AGE & 33 & 5 & 17 & 11,64 & 2,859 \\
\hline SIZE (CM) & 33 & 115,0 & 175,0 & 148,3333 & 15,46501 \\
\hline KILOGRAM (KG) & 33 & 22 & 83 & 47,79 & 16,221 \\
\hline
\end{tabular}


Age range is 5-17 in sample group. Age average is $11,64( \pm 2,859)$

Table 2. Gender

\begin{tabular}{|l|c|c|c|c|}
\hline & \multicolumn{2}{|c|}{ Turkish } & \multicolumn{2}{c|}{ French } \\
\hline Sex & N & \% & N & \% \\
\hline Women & - & & 2 & 10 \\
\hline Men & 13 & 100 & 18 & 90 \\
\hline Total & 13 & 100 & 20 & 100 \\
\hline
\end{tabular}

There are 2 females and 31 males in application group.

Table 3. Distribution of age by countries

\begin{tabular}{|l|l|l|l|}
\hline \multicolumn{2}{|c}{ Age } & f & \% \\
\hline \multirow{5}{*}{ Turkish Children } & 8 & 2 & 11,8 \\
\cline { 2 - 4 } & 9 & 4 & 23,5 \\
\cline { 2 - 4 } & 11 & 1 & 5,9 \\
\cline { 2 - 4 } & 12 & 5 & 29,4 \\
\cline { 2 - 4 } & 13 & 1 & 5,9 \\
\cline { 2 - 4 } & 15 & 2 & 11,8 \\
\cline { 2 - 4 } & 16 & 1 & 5,9 \\
\cline { 2 - 4 } & 17 & 1 & 5,9 \\
\cline { 2 - 4 } & Total & 13 & 100,0 \\
\hline \multirow{5}{*}{ French Children } & 5 & 1 & 6,3 \\
\cline { 2 - 4 } & 6 & 1 & 6,3 \\
\cline { 2 - 4 } & 9 & 1 & 6,3 \\
\cline { 2 - 4 } & 10 & 1 & 6,3 \\
\cline { 2 - 4 } & 11 & 3 & 18,8 \\
\cline { 2 - 4 } & 12 & 2 & 12,5 \\
\cline { 2 - 4 } & 13 & 3 & 18,8 \\
\cline { 2 - 4 } & 14 & 1 & 6,3 \\
\cline { 2 - 4 } & 15 & 20 & 100,0 \\
\cline { 2 - 4 } & 16 & & \\
\cline { 2 - 4 } & Total & 1 & 12,5 \\
\hline
\end{tabular}

It was determined that Turkish children are mainly at the ages of 8,9 and 12 and French children are in 11-14 age range by means of distribution of ages by countries.

Table 4. Cycling Learning Sessions of Children

\begin{tabular}{|l|l|l|}
\hline Seans & F & \% \\
\hline 3 & 1 & 3,0 \\
\hline 5 & 2 & 6,1 \\
\hline 6 & 1 & 3,0 \\
\hline 8 & 2 & 6,1 \\
\hline 10 & 3 & 9,1 \\
\hline 12 & 4 & 12,1 \\
\hline 15 & 3 & 9,1 \\
\hline 17 & 1 & 3,0 \\
\hline 18 & 2 & 6,1 \\
\hline 20 & 1 & 3,0 \\
\hline 22 & 1 & 3,0 \\
\hline 25 & 3 & 9,1 \\
\hline 26 & 1 & 3,0 \\
\hline 30 & 3 & 9,1 \\
\hline 31 & 1 & 3,0 \\
\hline 35 & 1 & 3,0 \\
\hline 36 & 1 & 3,0 \\
\hline 39 & 1 & 3,0 \\
\hline 40 & 1 & 3,0 \\
\hline Total & $\mathbf{3 3}$ & $\mathbf{1 0 0}$ \\
\hline & & \\
\hline
\end{tabular}


Considering cycling learning sessions of children, we see it is in 3-40 sessions range. Considering percent; we can say that more children became skillful at cycling between 1015 sessions.

Table 5. Comparison of Cycling Skills Preliminary Test/Last Data

\begin{tabular}{|l|l|l|l|l|l|l|l|}
\hline & $\mathbf{N}$ & Mean & Std. Deviation & Minimum & Maximum & $\mathbf{Z}$ & P \\
\hline First TEST & 33 & 12,91 & 4,397 & 10 & 22 & $-5,021$ & $\mathbf{, 0 0 0}$ \\
\cline { 1 - 5 } Last TEST & 33 & 26,21 & 4,256 & 18 & 30 & & \\
\hline
\end{tabular}

When comparing total points of preliminary test and posttest of cycling skills; a statistically meaningful difference was found.

Table 6. Pre test-Post test Data of Articles in Bicycle Observation Form (Survey)

\begin{tabular}{|c|c|c|c|c|c|c|c|c|c|c|}
\hline & $\begin{array}{c}\text { Saddle } \\
\text { know }\end{array}$ & $\begin{array}{c}\text { Pedal } \\
\text { know }\end{array}$ & $\begin{array}{c}\text { Handle } \\
\text { Bar } \\
\text { know }\end{array}$ & $\begin{array}{c}\text { Brake } \\
\text { know }\end{array}$ & $\begin{array}{c}\text { Sit on a } \\
\text { bicycle }\end{array}$ & $\begin{array}{c}\text { Right pedaling } \\
\text { on the bicycle }\end{array}$ & $\begin{array}{c}\text { Reading } \\
\text { bicycle on } \\
\text { balance }\end{array}$ & $\begin{array}{c}\text { Turning bicycle } \\
\text { with balance }\end{array}$ & $\begin{array}{c}\text { Acceralation by } \\
\text { the bicycle }\end{array}$ & $\begin{array}{c}\text { Brake on } \\
\text { bicycle }\end{array}$ \\
\hline $\mathrm{Z}$ & $-4,137$ & $-4,137$ & $-4,137$ & $-4,137$ & $-4,625$ & $-5,200$ & $-5,745$ & $-5,745$ & $-4,730$ & $-4,363$ \\
\hline $\mathbf{P}$ & $\mathbf{, 0 0 0}$ & $\mathbf{, 0 0 0}$ & $\mathbf{, 0 0 0}$ & $\mathbf{, 0 0 0}$ & $\mathbf{, 0 0 0}$ & $\mathbf{, 0 0 0}$ & $\mathbf{, 0 0 0}$ & $\mathbf{, 0 0 0}$ & $\mathbf{, 0 0 0}$ &, $\mathbf{0 0 0}$ \\
\hline
\end{tabular}

Considering questions of survey by articles, statistically meaningful difference was determined at all parameters.

\section{Discussion and conclusion}

It is emphasized in studies that activities including sports improved communication skills and physical capacities of children with autism and made current situation better. Bicycle as a sport and daily vehicle might be effective on children for recreation, communicating with friends, to improve physical capacity, to make contribution to consciousness and to grow self-confidence.

Recognizing bicycle and cycling skills of children with autism who need special support to maintain daily life and for social harmony were wanted to grow. There are 33 children in total including 20 French and 13 Turkish children with 5-17 age range. Studies carried out separately for each one lasted for 40 sessions and required skills were obtained between 5 40 sessions.

Considering cycling pre test/post test averages of our study; cycling skill which is $12,91 \pm 4,397$ at pre test increased to $26,21 \pm 4,256$ at posttest. Statistically meaningful difference was found at $\mathrm{p}<0.05$ level $(, 000)$.

Ardahan and Mert [12] researched the relation between students' physical conditions and duration of cycling learning and stated that children who like to move learn to cycle faster.

MacDonald and friends [13] applied individualized education method to children at at cycling upskilling study carried out with 30 individual with down syndrome and 41 individuals with autism. It was observed that $73.3 \%$ of children with down syndrome and $85.4 \%$ of children with autism could cycle for a distance longer than 100 meters at the end of 5 days of study.

Although duration of learning differs, every person in sample group participated in our research could obtain skill to cycle for more than 10 minutes.

Considering pre test and post test results of study carried out for children to recognize "saddle, pedal, handlebar and brake" which are parts of bicycle, statistically meaningful differences were determined $(, 000)$. We believe that children with autism learn concrete conceptions easier as they have trouble learning abstract conceptions. Using sports activity in teaching concepts will contribute education. 
Doğru and friends [14] To ride a bicycle with balanced tires is taught 3 children with autism in 3-6 age range by direct education method. However, we think that riding bicycle with balanced tires causes to delay riding bicycles with two tires and leads individuals with autism having habit to put their weight on one side.

Statistically meaningful differences were determined as a result of pre test and post test comparison of behaviors including ability to sit on bicycle (saddle), to cycle correctly, to balance on bicycle, to make turns on bicycle, ability to brake, to make departure on bicycle on our study made concerning ability to ride bicycle with two tires $(, 000)$.

Yanardağ and friends [15], Elaltunkara and Cengiz [16], Gök and Başaran [10] stated that 16-weeks exercise education they provided for children with autism affected their basic motor skills and subjects on daily life positively, improved them and increased their life quality Alp and Çamlıyer [17] observed decrease in problematical behaviors of children who do physical activity. It was seen that individual with autism who does physical activity grows better comparing with individual with autism who does not do physical activity. [18, $19,20]$.

As a conclusion: Education to recognize bicycle and to cycle affected children with autism positively and all children in our sample group learnt how to ride bicycle with two tires. This result was found meaningful in pre test and post test point results statistically. Skills and disciplines brought by correct approaches to groups needing this type special education in order to maintain their daily life will help them to grow and to maintain a happier life.

\subsection{Recommendations}

- Only education to recognize bicycle and to cycle was given in this study. Education programs for requested behavior change or skill acquisition may be prepared and given depending on child's capacity.

- As this study is based on one-to-one teaching method, it was carried out with limited number of students. Its background may be prepared by the state in order to apply this on all children with autism.

- As this kind of education requires a special leadership and fund of knowledge, sufficient number of leaders should be raised. It should be followed step by step as it is in coaching.

\section{References}

1. E. T. İftar, Otizm Spektrum Bozukluğu Olan Çocuklar ve Eğitimleri, 3.baskı Vize Yayıncılık, Ankara (2014)

2. O. I. Lovaas, Ben Kitabı (Çevirmen: Sorias, O, Gürkan, A., Tekinsav Sütçü, S., Çengelci, B., Yılmaz Irmak T.) Sistem yayınevi, İstanbul 1.Baskı ISBN No: 9753224036 (2005)

3. L. Wing, Otizm El Rehber (Çevirmen: Kurt S.) Yayınevi Sistem İstanbul 3. Bask1 ISBN No: 9786054463657 (2010)

4. A. Özen, Özel Gereksinimli Bireyler Ve Bakım Hizmetleri Anadolu Üniversitesi Yayınları p.15-43 Eskişehir (2012)

5. A. Baniel, Sınırları Aşan Çocuklar (Çevirmen: Dalar, Y.), Doğan Yayınevi, İstanbul, ISSN 9786050930955 (2015)

6. B. Korkmaz Ah şu Otizm Aba yayınevi, İstanbul, ISBN: 978-605-66593-7-9 (2017) 
7. N. Motavalli, Oizm Spektrum Bozukluklarl, Erişim Tarihi: 19.03.2018 http://www.inca2014.com/sunular/turkce/Nahit\%20Motavalli\%20Mukaddes.pdf (2014)

8. W. Chung, Otizm Hakkında Bildiklerimiz ve Henüz Bilmediklerimiz Erişim Tarihi : 15 Mayıs 2018 https://www.youtube.com/watch?v=JzRsYJ0bzE8_(2014)

9. S. Benson, What is autism spectrum disorder, Erişim Tarihi: 19 Mart 2018, https://www.psychiatry.org/patients-families/autism/what-is-autism-spectrum-disorder (2016)

10. E. Gök, Z. Başaran, Spor Eğitimin 6-17 Yaş Otistik Çocuklarda Duyusal ve Davranış Problemlerine Etkisi, Uluslararası Herkes İçin Spor ve Wellness Kongresi, 05-08 Nisan 2018, Antalya, Alanya (2018)

11. D. Erbaş, Y.Ş. Özkan, Uygulamalı Davranış Analizi Yayınevi, Pagem, İstanbul, ISBN: 6052411414 (2017)

12. F. Ardahan, M. Mert, Bisiklet Kullanan Bireylerin Profillerinin Belirlenmesi ve Bireyleri Bisiklet Kullanmaya Motive Eden Faktörlerin Çeşitli Demografik Değişkenlere Göre Değerlendirilmesi: Türkiye Örneği, Türkiye Klinikleri Journal of Sports Sciences, 6(2): 53-67 (2014)

13. M. Macdonald, P. Esposito, J. Hauck, I. Jeong, J. Hornyak, A. Argento, D.A Ulrich, Bicycle Training For Youth With Down Syndrome And Autism Spectrum Disorders Focus On Autism And Other Developmental Disabilities :27(1) p: 12-21 (2012)

14. S.S.Y. Doğru, Ö.B.Y Önal, H. Bek, Teaching How Tor İde A Blanche Wheeled Bicycle To Autistic Children Using The Direct Instruction Method, Selçuk Üniversitesi Sosyal Bilimler Enstitüsü Dergisi (18) p:245-256 ISSN No: 1302-1796 (2007)

15. M. Yanardağ, N. Ergun, Y. İlker, Otistik Çocuklarda Adapte Edilmiş Egzersiz Eğitiminin Fiziksel Uygunluk Düzeyine Etkisi Fizyoterapi Rehabilitasyon 20(1) p:25-31 (2009)

16. C. Elaltunkara, R. Cengiz, 16 Haftalık Spor Ĕgitiminin Otizmli Çocuklarda Temel Motor Becerileri Üzerine Etkisi, Bartın Üniversitesi Beden Eğitimi ve Spor Öğretmenliği Anabilim Dalı, Yayınlanmamış Yüksek Lisans Tezi, Bartın (2017)

17. H. Alp, H. Çamllyer, Otistik Çocuklarda Görülen Davranış Problemlerinin Düzeltilmesiyle Hareket Ĕ̈itimi Ve Fiziksel Aktivitelerin İlişkisi, Eğitim ve Öğretim Araştırmaları Dergisi, 5(2/26): 252-264, ISSN: 2146-9199 (2016)

18. S. Naml1, Spor Yapan ve Yapmayan Otistik Engelli Bireylerin Davranış Ve Motor Performanslarının Karşılaştırılması (Yayınlanmamış Yüksek Lisans Tezi). Sakarya Üniversitesi, Eğitim Bilimleri Enstitüsü, Sakarya (2012)

19. B. Görgün, M.A. Melekoğlu, Otizm Spektrum Bozukluğu (Osb) Olan Bireylerin Fiziksel Aktivitelerine İlişkin Yapılan Çalışmaların Gözden Geçirilmesi, Ankara Üniversitesi Eğitim Bilimleri Fakültesi Özel Eğitim Dergisi, 17(3), p: 347-376 (2016)

20. B. Kavlak, B. Bayazıt, Otizmli Bireylere Uygulanan Bireyselleştirilmiş Egzersiz Eğitiminin Motor Gelişimine Etkisi, Uluslararası Rekreasyon ve Spor Yönetimi Kongresi, 10-13 Mayıs 2018, Bodrum-Türkiye (2018) 